\title{
ANALISIS TREN NILAI TUKAR PETANI TANAMAN PANGAN PROVINSI KEPULAUAN BANGKA BELITUNG
}

\author{
Apriyono \\ Badan Perencanaan Pembangunan dan Penelitian Pengembangan Daerah Provinsi \\ Kepulauan Bangka Belitung, \\ Jl. Pulau Bangka, Kel. Air Itam, Kec. Bukit Intan, Pangkalpinang, 33149 - Bangka \\ Belitung, Indonesia \\ E-mail: apri.tsaqiifalkindi@gmail.com
}

\begin{abstract}
The sustainability of rice or food crop farming depends on the level of welfare of the farmers. One approach to measuring the purchasing power of farmers in rural areas is the Farmer Exchange Rate (NTP). The purpose of this study was to determine the development of the achievement level of the Exchange Rate of food crop farmers in Bangka Belitung from 2013-2020 with the method of analysis using quantitative descriptive methods. The results showed that the average farmer exchange rate from 2013-2020 was 93.98 percent, still below the index value of 100 , which means that food crop farmers in Kepulauan Bangka Belitung Province are still not prosperous.
\end{abstract}

Keywords: Farmer Exchange Rate; Food Crops; Welfare

\section{PENDAHULUAN}

Bangka Belitung merupakan daerah dengan kondisi geografis berbentuk kepulauan dan sejak lama dikenal sebagai daerah pertambangan. Maka wajar saja awalnya fokus pembangunan ekonomi lebih ditujukan pada upaya menggenjot pertumbuhan ekonomi melalui peningkatan sektor pertambangan. Seiring perubahan waktu orietasi pembangunan ekonomi daerah dalam beberapa tahun terkhir telah bertransformasi ke berbagai sektor ekonomi laindi luar sektor pertambangan diantaranya sektor pertanian.

Dalam beberapa tahun terakhir pertumbuhan sektor pertanian di Bangka Belitung mulai menunjukan perkembangan dengan terus meningkatnya produksi tanaman pangan khususnya padi. Data Dinas Pangan Provinsi Kepulauan Bangka Belitung (2020) menunjukan tingkat ketergantungan pangan khususnya beras Bangka Belitung dari luar daerah tahun 2015 sampai dengan tahun 2020 terus menunjukan penurunan. Pada tahun 2015 tingkat kergantungan akan beras sebesar 86,52 persen kemudian menjadi 72,90 persen pada tahun 2020. Hal ini menjadikan sektor pertanian khususnya tanaman pangan perlu terus didorong agar mampu berperan lebih optimal lagi dalam menyokong kebutuhan pangan lokal.

Dalam menjaga ketahanan pangan sekaligus meningkatkan pendapatan petani maka peran sangat penting dan strategis. Selain itu sektor pertanian merupakan sektor yang berhubungan erat dengan kehidupan manusia. Apalagi tuntutan akan pangan dimasa mendatang yang kian meningkat menjadi tantangan bagi sektor pertanian. Penelitian Simatupang (1992) dalam Rachmat (2000) menyatakan bahwa besarnya peran sektor pertanian bagi pembangunan suatu negara terlebih negara berkembang karena merupakan sektor perekonomian berbasis sumber daya lokal.

Tantangan sektor pertanian ke depan bukan sekedar bagaimana meningkatkan ketersediaan produk pertanian tetapi juga bagaimana meningkatkan kesejahteraan petani. Hal ini karena kesinambungan usaha tani padi atau pangan tergantung pada tingkat kesejahteraan petani itu sendiri. Menurut Suhariyanto (2021) tingkat kesejahteraan petani 
tidak terlalu mengalami peningkatan yang signifikan setiap tahunnya. Hal tersebut karena petani harus berpacu dengan inflasi. Apalagi setiap tahunnya upah buruh tani hanya mengalami peningkatan sangat kecil. Padahal kenaikan produksi tidak berbanding lurus dengan kenaikan Nilai Tukar Petani (NTP). Tingkat harga jual komoditas petani merupakan faktor yang cukup berpengaruh terhadap NTP (jurnalmilenial.com)

Sementara Nurasa dan Rachmat (2013) dalam penelitiannya menyatakan bahwa saat produksi padi yang biasanya terjadi pada bulan April-Mei, umumnya nilai tukar padi berada pada posisi yang rendah sehingga menyebabkan NTP juga pada posisi yang rendah pula. Sedangkan pada bulan Desember-Januari yang merupakan saat masa paceklik NTP -padi berada pada posisi tertinggi. Harga jual yang menurun di saat produksi puncak mengakibatkan NTP padi mengalami penurunan. Kebijakan nilai dasar gabah yang belum efektif serta petani sebagai penerima harga dalam sistem tataniaga menjadi penyebab hal ini terjadi. Kondisi tersebut berimplikasi kepada: (a) agar kenaikan hasil produksi berpengaruh positif terhadap kenaikan NTP maka pengukuran NTP tidak cukup berbasiskan pada perbandingan nilai barang/produk, (b) agar harga jual petani tidak berfluktuatif maka pentingnya mempertahankan kebijakan harga dasar gabah agar dapat efektif, dan (c) penundaan masa penjualan gabah petani melalui pengembangan sistem pendanaan. Kebutuhan dana tunai menyebabkan mayoritas petani setelah panen menjual hasil produksinya. Menunda penjualan hasil panen selain memperbaiki skema cadangan pangan dan penyaluran padi nasional juga menjadikan nilai jual padi meningkat yang tentu saja akan menguntungkan petani. Sementara menurut Racmat et al. (2000) menyatakan bahwa di Indonesia kekhasan dari Nilai Tukar Petani cenderung mengalami penurunan. NTP erat kaitanya dengan harga komoditas pertanian dan non pertanian yang berhubungan relatif. Konsep perhitungan barter pertanian terhadap nonpertanian bisa digunakan untuk melihat fenomena penurunan nilai tukar pertanian. Setidaknya ada tiga alasan mengapa NTP mengalami tren yang melemah: (1) fleksibilitas penerimaan barang pertanian yang tidak fleksibel, (2) diuntungkannya produk manufaktur akibat laju perubahan teknologi yang berbeda dari dan (3). Lebih kompetitifnya pasar produk pertanian dibandingkan struktur pasar manufaktur karena struktur pasar yang berbeda

Selain statistik tentang perkembangan ekonomi untuk melihat kemajuan pembangunan juga diperlukan data pengukur kapasitas daya tukar petani sebagai aktor utama di pertanian. Cara melihat kapasitas daya tukar petani salah satunya adalah Nilai Tukar Petani (NTP). Perbandingan antara penerimaan harga hasil usaha pertanian yang dinikmati petani terhadap jumlah pengeluaran yang dikeluarkan petani dikenal dengan istilah NTP. Dalam bahasa lain NTP merupakan instrumen kapasitas nilai jual hasil pertanian terhadap konsumsi petani dalam menghasilkan produk pertanian (Hendayana, 2001). Kesejahteraan petani akan meningkat apabila nilai tambahnya meningkat atau terdapat nilai lebih antara hasil dan biaya produksi yang dikeluarkan. Sehingga besar kecilnya nilai tambah petani menentukan tingkat NTP yang diperoleh. Menurut Masyhuri (2007) penanda relatif tingkat kemakmuran petani salah satunya adalah NTP, dimana makin tinggi nilai NTP, maka tingkat kehidupan petani semakin sejahtera.

Penelitian ini bertujuan untuk mengetahui perkembangan tingkat capaian Nilai Tukar Petani tanaman pangan di Bangka Belitung tahun 2013-2020. Kondisi tersebut dapat dimanfaatkan pemerintah sebagai gambaran tentang perkembangan kesejahteraan masyarakat dalam periode tersebut. Selanjutnya gambaran tersebut menjadi pedoman bagi pemerintah dalam mengambil kebijakan yang sesuai harapan masyarakat. 


\section{METODE PENELITIAN}

\section{Metode Pengumpulan Data}

Penelitian ini menggunakan data Nilai Tukar Petani komoditas Pangan Provinsi Kep. Bangka Belitung rentang waktu 2013-2020 yang bersumber dari Badan Pusat Statistik (BPS, 2021). Adapun metode analisisnya menggunakan metode diskriftif kuantitatif.

\section{Tahap Analisis Data}

Nilai tukar petani (NTP) sering dipakai sebagai ukuran menilai tingkat kemakmuran petani. NTP merupakan perbandingan antara penerimaan petani dari hasil pertanian terhadap pengeluaran petani dalam hal ini barang konsumsi dan kebutuhan petani dalam berproduksi. NTP selalu berubah-ubah tiap saat dipengaruhi kondisi terbaru nilai produk yang dinikmati petani (It) dan nilai produk yang dibayar petani (Ib). NTP akan naik jika persentase kenaikan harga produk yang dihasilkan petani melebihi dari persentase peningkatan produk yang dibayar petani, yang berarti petani mendapatkan kenaikan pendapatan/penerimaan. Sehingga secara umum terdapat keterkaitan erat antara nilai tambah pendapatan petani dengan NTP. Biasanya antara penerimaan petani dan kesejahteraan/tingkat kemakmuran petani memiliki korelasi yang positif, maka NTP merupakan alat ukur yang tepat dalam menggambarkan kenaikan kesejahteraan petani (BPS, 2006; Masyhuri, 2007).

Rumus perhitungan Nilai Tukar Petani (NTP) :

$$
\mathrm{NTP}=\mathrm{It} / \mathrm{Ib} \times 100
$$

dimana:

$$
\begin{aligned}
& \text { NTP = Nilai Tukar Petani } \\
& \text { It = Indeks harga yang diterima petani } \\
& \text { Ib = Indeks harga yang dibayar petani }
\end{aligned}
$$

Ada tiga pengertian dari hasil perhitungan NTP di atas_(BPS, 2019). Pertama, NTP $>100$, berarti penerimaan petani lebih tinggi dari pengeluaran petani atau petani memperoleh keuntungan dari hasil usahanya. Kedua, NTP $=100$, berarti antara penerimaan dan pengeluaran petani sama besarnya atau hasil usaha petani hanya mampu menutupi pengeluaran usaha pertanian. Dan ketiga, NTP $<100$, berarti pengeluaran petani melebihi jumlah penerimaan petani atau petani mengalami kerugian. 


\section{HASIL DAN PEMBAHASAN}

Hasil penelitian dengan menggunakan data NTP tanaman pangan Provinsi Kepulauan Bangka Belitung tahun 2013-2020 selanjutnya digambarkan dalam grafik berikut:

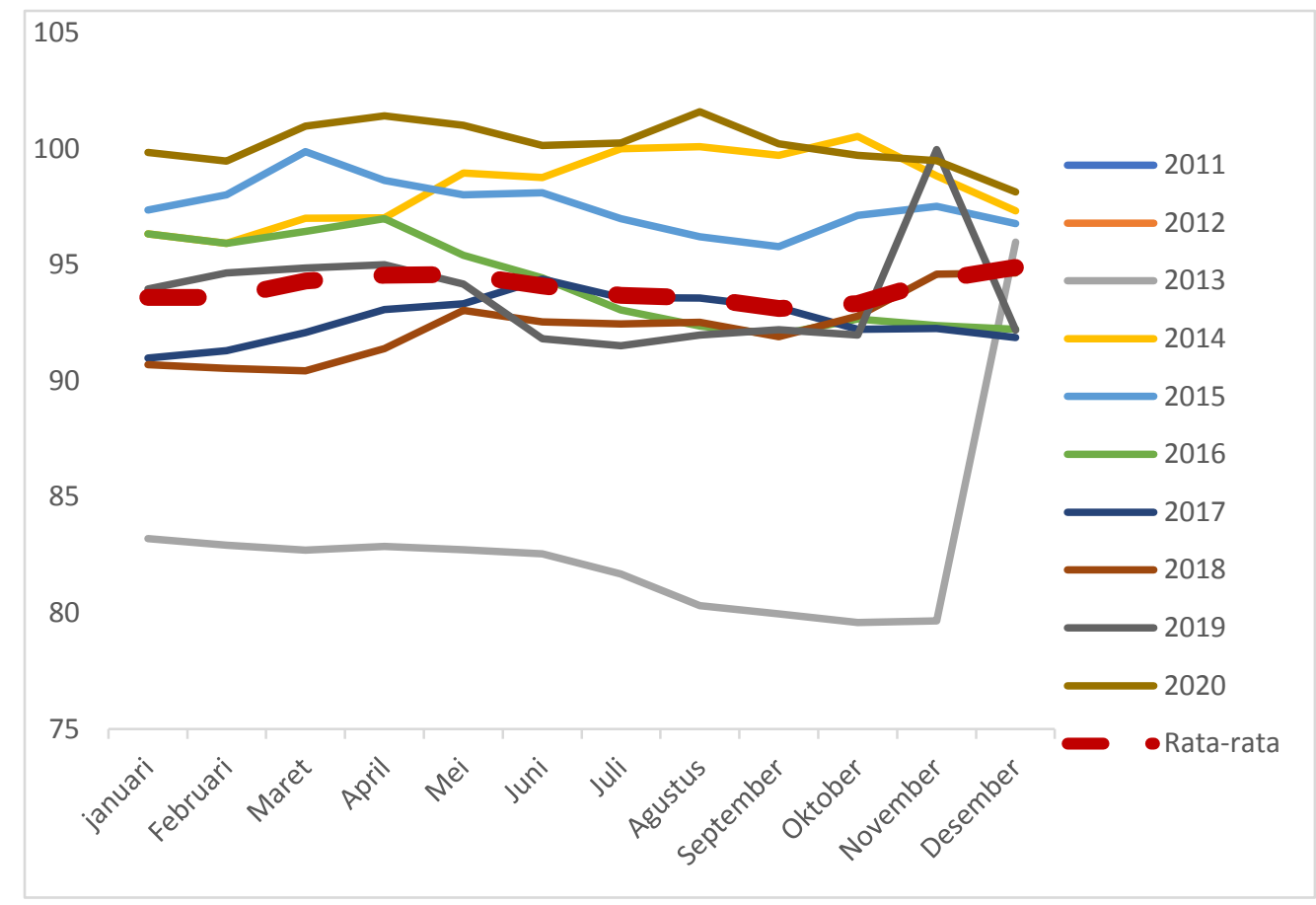

Gambar 1. Grafik perkembangan nilai tukar petani (NTP) pangan Bangka Belitung tahun 2013-2020 $(2012=100)$

Dari gambar grafik di atas, memperlihatkan bahwa NTP petani tanaman pangan 2013 sampai dengan 2020 menunjukkan tren yang fluktuatif, namun terjadi peningkatan yang signifikan dalam kurun waktu 2 tahun terakhir (2019 ke 2000). NTP terendah terjadi pada tahun 2013 dimana sempat terjadi penurunan pada bulan Januari sampai pada bulan November kemudian mengalami kenaikan yang cukup signifikan pada bulan Desember 2013 namun secara umum NTP tahun 2013 merupakan NTP terendah dalam interval waktu tahun 2013-2020. Sementara NTP tertinggi terjadi di tahun 2020 dimana nilai tukar berfluktuasi antar bulan namun secara tahunan merupakan capaian NTP tertinggi dalam kurun waktu 2013-2020. Selanjutnya untuk NTP tahun 2014 sampai 2019 menunjukan kondisi yang berfluktuatif dari bulan ke bulan dalam satu tahun maupun dari tahun ke tahun namun cendrung meningkat.

Jika dilihat dari tingkat rata-rata NTP tahunan maupun bulanan selama tahun 20132020 diperoleh NTP tahunan maupun bulanan rata-rata sebesar 93,98. Selanjutnya dapat dilihat nilai NTP yang berada dibawah Nilai NTP rata-rata maupun Nilai NTP diatas ratarata. Untuk NTP yang berada dibawah NTP rata-rata tahunan yaitu NTP pada tahun 2013, 2017, 2018 dan 2019, sedangkan nilai NTP diatas NTP rata-rata tahunan yaitu NTP tahun 2014, 2015 serta 2020. Adapun jika dilihat dari NTP dibawah NTP rata-rata bulanan maka ada di bulan Januari, Februari, Agustus, September dan Oktober. Sementara NTP diatas NTP rata-rata terjadi pada Maret, April, Mei, Juni, November serta Desember.

Beberapa fenomena yang menarik melihat grafik perkembangan NTP di atas. Jika kita lihat tahun 2013 merupakan tahun dimana NTP terendah. Hal tersebut disebabkan 
harga bahan bakar minyak yang mengalami kenaikan dan disertai terjadinya inflasi sehingga harga kebutuhan konsumsi sehari-hari termasuk biaya produksi pertanian naik lebih cepat dibandingkan kenaikan harga produk pertanian. Kenaikan BBM mempengaruhi Nilai Tukar Petani karena meningkatnya harga barang untuk memproduksi hasil pertanian (Ipango dkk., 2017). Sedangkan grafik NTP tahun 2020 lebih tinggi dari NTP tahun-tahun sebelumnya disebabkan oleh adanya dorongan sejumlah kebijakan pemerintah daerah dalam mewujudkan ketahanan dan kemandirian pangan di Bangka Belitung khususnya di masa pandemi Covid-19 melalui pembangunan sektor pertanian (republika.co.id,2021).

NTP rata-rata bulanan dalam satu tahun di bawah angka NTP rata-rata tahunan tersebut dipengaruhi oleh faktor iklim/cuaca sehingga mempengaruhi produksi petani (puncak musim hujan/banjir = Januari-Februari serta Agustus, September Oktober $=$ musim kemarau). Daerah-daerah pada zona beriklim tropis maupun sub tropis, tergolong didalamnya Sumatra, sebagian kecil wilayah Jawa dan Kalimantan merupakan daerah yang mengalami banjir ketika musim hujan serta mengalami kekeringan ketika musim kering sehingga mengalami gagal panen (Reilly, 1996; UNFCCC, 2002). Hal yang sama menurut Sudarma, dkk (2018) menyatakan bahwa akibat pemanasan global menyebabkan perubahan iklim yang tidak terelakan yang berakibat luas di berbagai lini kehidupan termasuk sektor pertanian

Sedangkan NTP rata-rata bulanan di atas NTP rata-rata bulanan dalam satu tahun disebabkan bulan-bulan (Maret, April, Mei, Juni, November dan Desember) tersebut merupakan moment-moment perayaan hari besar keagamaan/nasional dimana kebutuhan produk pertanian dibutuhkan dalam jumlah yang banyak.

Secara umum berdasarkan grafik diatas, NTP Provinsi Kepulauan Bangka Belitung selama tahun 2013-2020 masih berada dibawah angka $100(93,98)$. Hanya pada tahun 2020 NTP Provinsi Kepulauan Bangka Belitung berada angka 100. Kondisi tersebut menggambarkan kemampuan bayar petani di Bangka Belitung yang kurang baik dibandingkan kondisi petani pada tahun 2012 (tahun dasar). Nilai Tukar Petani yang berada dibawah 100, mengindikasikan nilai tukar hasil produksi lebih banyak tergerus oleh tingginya harga barang kebutuhan konsumsi dan biaya proses produksi. Hal ini menyebabkan pendapatan dari hasil produksi belum mampu mengimbangi pesatnya laju pertumbuhan harga barang dan jasa di pasar eceran.

Untuk melihat perkembangan NTP Pangan Provinsi Kep.Bangka Belitung pada tahun 2013-2020 dapat digambarkan dari trend (arah) persamaan regresi dari koefisien waktu gambar 2. Dari Gambar terlihat NTP Pangan tahun 2013-2020 di Provinsi Kep. Bangka Belitung cenderung memperlihatkankan peningkatan yang ditunjukkan oleh angka koefisien laju NTP pangan yang bernilai positif, sesuai dengan hasil hipotesa parameter persamaan NTP pangan dibawah: 


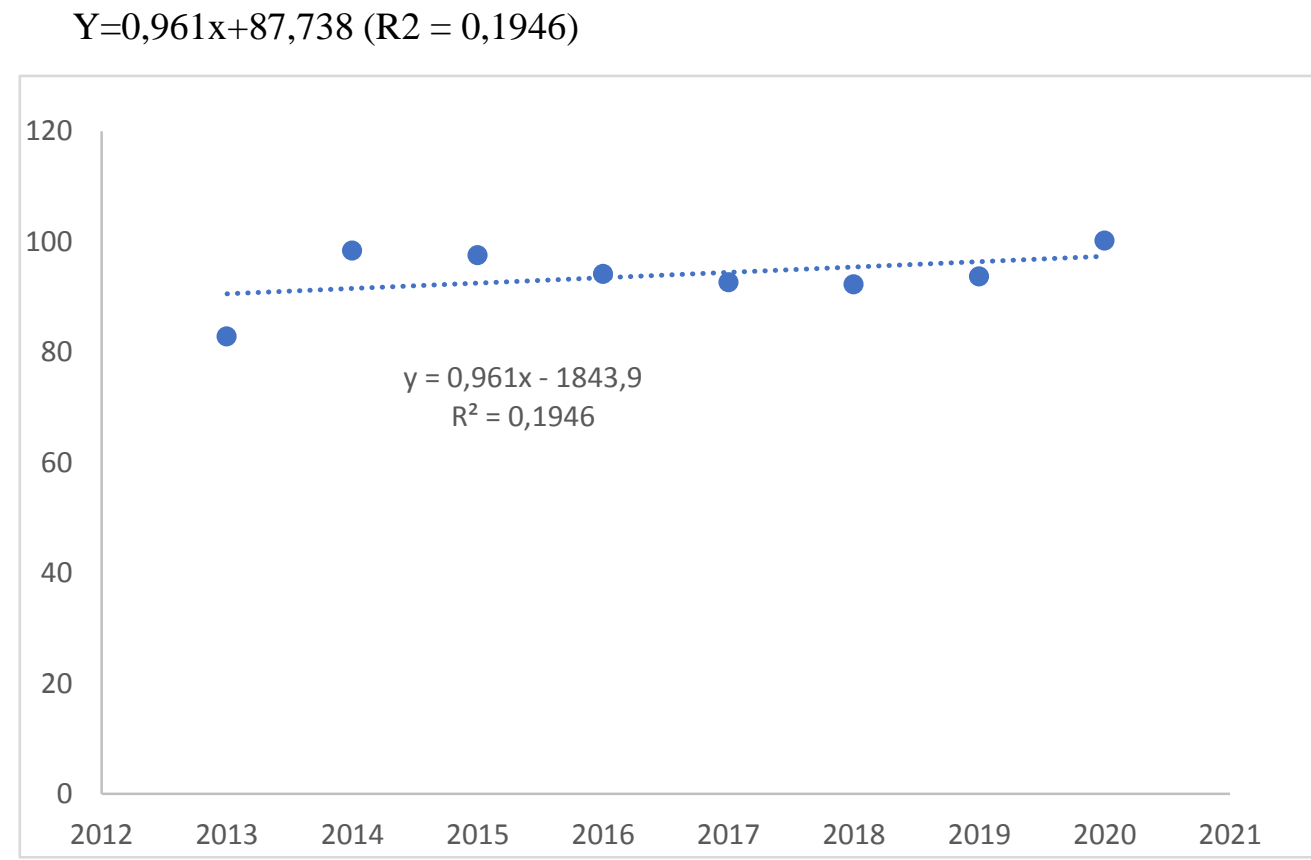

Gambar 2. Grafik kecendrungan perkembangan nilai tukar petani pangan Bangka Belitung tahun 2013-2020 (2012=100)

Untuk meningkatkan NTP secara matematis adalah dengan melakukan beberapa program/kegiatan (kebijakan) guna meningkatkan penerimaan petani dan menurunkan tingkat pengeluaran petani. Dalam upaya meningkatkan tingkat penerimaan petani dapat dilakukan melalui strategi peningkatan hasil panen dan nilai jual produk pertanian. Maknanya adalah bahwa tujuan pembangunan pertanian tidak hanya menstimulan produksi agar memberikan hasil yang optimal namun juga memberikan dampak pada tingkat penerimaan dan kemakmuran petani. Kebijakan peningkatan hasil panen bisa dilakukan baik melalui kegiatan pengintensifan lahan pertanian yang telah ada, pembukaan/pengembangan areal tanam baru, maupun frekuensi indeks pertanaman (IP) yang ditambah.

Pengintensifan lahan pertanian ada antara lain melalui penggunaan bibit unggul, penggunaan pupuk berimbang antara pupuk organik dan anorganik serta budidaya dengan menerapkan Good Agricultural Practices (GAP) Sedangkan untuk indeks pertanaman dilakukan dengan penanaman beberapa kali dalam satu tahun dengan dukungan perbaikan irigasi, embung dan bantuan sarana prasarana produksi. Upaya lain yaitu meningkatkan pendapatan petani dapat dilakukan dengan memotong saluran pemasaran, bantuan sistem permodalan yang mudah dan murah, jaminan harga hasil produksi serta peningkatan nilai tambah hasil produksi melalui pengolahan hasil.

Pengeluaran petani dipengaruhi oleh faktor beban pengeluaran pangan petani sehari-hari dan beban ongkos menghasilkan produk pertanian (biaya produksi). Untuk itu upaya menurunkan biaya produksi merupakan opsi yang paling mungkin untuk dilakukan. Sehingga agar NTP dapat mengalami peningkatan tiap tahun, maka tingkat pertambahan penerimaan petani harus melebihi tingkat pertambahahan pengeluaran petani, dalam hal ini beban ongkos/biaya produksi. Artinya laju kenaikan ongkos menghasilkan produk pertanian diperlambat sedangkan nilai dan kuantitas hasil pertanian diupayakan naik dengan cepat. 


\section{KESIMPULAN}

Perkembangan Nilai Tukar Petani Pangan Bangka Belitung tahun 2013-2020 menunjukkan tren peningkatan. Semula pada tahun 2013 sebesar 82,86 persen terus mengalami peningkatan sampai dengan 100,21 persen pada tahun 2020. Akan tetapi jika dilihat dari perkembangan rata-rata tahunan NTP Pangan Bangka Belitung masih dibawah pada indeks nilai $100(93,98)$. Hal ini menunjukan bahwa tingkat kesejahteraan petani Bangka Belitung masih rendah karena nilai tukar hasil produksi lebih banyak tergerus oleh tingginya harga barang kebutuhan konsumsi dan biaya proses produksi, sehingga menyebabkan pendapatan dari hasil produksi belum mampu mengimbangi pesatnya laju pertumbuhan harga barang dan jasa di pasar eceran.

\section{DAFTAR PUSTAKA}

BPS. 2006. Statistik Nilai Tukar Petani di Indonesia. Badan Pusat statistik. Jakarta

BPS. 2019 Statistik Nilai Tukar Petani Provinsi Kepulauan Bangka Belitung 2019

BPS Provinsi Kepulauan Bangka Belitung, Provinsi Kepulauan Bangka Belitung Dalam Angka 2021, OBPS Provinsi Kepulauan Bangka Belitung, ISSN: 1693 - 086X / No. Publikasi 19560.2101.

Bidang Ketersediaan Pangan, Laporan Penganekaragaman Konsumsi Pangan Dinas Pangan Provinsi Kepulauan Bangka Belitung Tahun 2020

Hedayana, R. 2001 Analisis Faktor-Faktor Yang Mempengaruhi Nilai Tukar Petani. Makalah Seminar Nasional Penelitian dan Pengembangan Agribisnis Berbasis Sumberdaya Lokal dan Teknologi Ramah Lingkungan di Balai Pengkajian Teknologi Pertanian Sulawesi Utara Manado, 26-27 November 2001.

Ipango, dkk. 2017. Agri-Sosio Ekonomi Unsrat, ISSN 1907-4298, Volume 13 Nomor 3 A, Juli 2017 : $91-98$

Masyhuri, 2007. Revitalisasi Pertanian Untuk Mensejahterakan Petani. Makalah pada Konpernas XV dan Kongres XIV PERHEPI, Surakarta, 3-5 Agustus 2007.

Nurasa, T. dan Rachmat, M. 2013. Nilai tukar petani padi sentra produksi padi di Indonesia. Jurnal Agro Ekonomi, 31(2), 161-179.

Rachmat, M. 2000. Analisis Nilai Tukar Petani Indonesia. Disertasi. Institut Pertanian Bogor

Reilly, John. 1996. Climate Change, Global Agricultura and Regional Vulnerability. FAO.

Simatupang, P. 1992. Pertumbuhan Ekonomi dan Nilai Tukar Barter Sektor Pertanian. Jurnal Agroekonomi. 11(1):37-50.

Sudarma, dkk. 2018. Dampak Perubahan Iklim Terhadap Sektor Pertanian Di Bali. Jurnal Sosial-Ekonomi Pertanian dan Agribisnis

UNFCCC. 2002. Climate Change Information Kit

https://jurnalmilenial.com/bps-kesejahteraan-petani-terancam-tergerus-inflasi/

https://republika.co.id/berita/daerah/sumatra/qo6vdg380/nilai-tukar-petani-babeltertinggi-di-indonesia Senin 08 Feb 2021 09:39 WIB 